\title{
PENGARUH MODAL SENDIRI DAN DANA PIHAK KETIGA TERHADAP RETURN ON INVESMENT (ROI)
}

\author{
Pada PD. BPR PK Balongan Indramayu \\ Effect Of Networth And Third Party Funds On Return On Invesment \\ (ROI) at PD. BPR PK Balongan Indramayu
}

\author{
Fitria Damayanti, Ika Widyastuti \\ Universitas Wiralodra, Jln.Ir.H. Juanda Km.03 Indramayu \\ fitria.damayanti@unwir.ac.id
}

\begin{abstract}
ABSTRAK
Dalam melakukan penelitian, peneliti melihat secara konkrit dan akurat dengan mengumpulkan data laporan keuangan PD BPR PK Balongan dari tahun 2012 sampai tahun 2017. Untuk menganalisis data peneliti melakukan analisis, korelasi, koefisien determinan, uji hipotesis parsial dan simultan. Berdasarkan analisis, didapatkan koefisien korelasi Modal Sendiri terhadap Return on Invesment (ROI) sebesar 0,38 yang berarti Modal Sendiri mempunyai hubungan yang rendah dan berbanding terbalik terhadap Return on Invesment (ROI). Nilai koefisien determinasi yang diperoleh sebesar 14,44\%, hal ini menunjukan bahwa Modal Sendiri mempunyai kontribusi terhadap Return on Invesment (ROI) sebesar 14,44\%, adapun sisanya dipengaruhi oleh faktor lain, dan berdasarkan hasil yang diperoleh dalam uji hipotesis adalah bahwa thitung $=\mathbf{0 , 8 2 2}$ sedangkan dari Ttabel 2,776 dengan taraf kesalahan 5\% sebesar 2,776. Atau - 1,720 < 2,776 sehingga $\mathrm{HO}$ diterima dan Ha ditolak. Koefisien korelasi Dana Pihak Ketiga terhadap Return on Invesment (ROI) sebesar 0,67 yang berarti Dana Pihak Ketiga mempunyai hubungan yang kuat dan berbanding terbalik terhadap Return on Invesment (ROI). Nilai koefisien detrminasi yang diperoleh sebesar 44,89 \%, hal ini menunjukan bahwa Dana Pihak Ketiga mempunyai kontribusi terhadap Return on

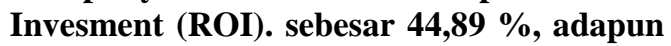
sisanya dipengaruhi oleh faktor lain, dan berdasarkan hasil yang diperoleh dalam uji hipotesis adalah bahwa thitung $=\mathbf{1 , 8 0 5}$ sedangkan dari Ttabel 2,776 dengan taraf kesalahan 5\% sebesar 2,776. Atau 1,805< 2,776 sehingga H0 diterima dan Ha ditolak. Koefisien korelasi Modal Sendiri dan Dana
\end{abstract}

Pihak Ketiga secara bersama- sama terhadap Return on Invesment (ROI) sebesar 0,42 yang berarti Modal Sendiri dan Dana Pihak Ketiga secara bersama-sama mempunyai hubungan yang sedang dan searah terhadap Return on Invesment (ROI). Nilai koefisien determinasi yang diperoleh sebesar 16,81\%, hal ini menunjukan bahwa Modal Sendiri dan Dana Pihak Ketiga secara bersama-sama mempunyai kontribusi terhadap Return on Invesment sebesar 16,81\%, adapun sisanya dipengaruhi oleh faktor lain, dan berdasarkan hasil yang diperoleh dalam uji hipotesis adalah bahwa thitung $=0,302$ sedangkan dari Ttabel dengan taraf kesalahan 5\% sebesar 9,55. Atau 0,302<9,55 sehingga $\mathrm{HO}$ diterima dan Ha ditolak.

Kata Kunci: Modal Sendiri, Dana Pihak Ketiga, ROI

\section{ABSTRACT}

In conducting research, researchers look concretely and accurately by collecting PD Balongan PK BPR financial report data from 2012 to 2017. To analyze the data the researchers conducted analyzes, correlations, determinant coefficients, partial and simultaneous hypothesis tests. Based on the analysis, it was found that the correlation coefficient of Networth towards Return on Investment (ROI) was 0.38 which means that Networth has a low relationship and inversely proportional to Return on Investment (ROI). The coefficient of determination obtained is $14.44 \%$, this shows that Networth has a contribution to Return on Investment (ROI) of $14.44 \%$, while the rest is influenced by other factors, and based on the results obtained in hypothesis testing is that tcount $=\mathbf{0 . 8 2 2}$ while 
Fitria Damayanti, Ika Widyastuti

from Ttable $\mathbf{2 . 7 7 6}$ with a $5 \%$ error rate of 2.776. Or - 1,720 $<2,776$ so that $\mathrm{HO}$ is accepted and $\mathrm{Ha}$ is rejected. Third Party Funds correlation coefficient on Return on Investment (ROI) of 0.67 which means Third Party Funds have a strong relationship and inversely proportional to Return on Investment (ROI). The detrmination coefficient obtained is $\mathbf{4 4 . 8 9 \%}$, this shows that Third Party Funds contribute to Return on Investment (ROI). amounting to $44.89 \%$, while the rest is influenced by other factors, and based on the results obtained in hypothesis testing is that tcount $=\mathbf{1 . 8 0 5}$ while from Ttable $\mathbf{2 . 7 7 6}$ with a $\mathbf{5 \%}$ error rate of 2.776. Or $1.805<2.776$ so that $\mathrm{HO}$ is accepted and $\mathrm{Ha}$ is rejected. Networth and ThirdParty Fund correlation coefficients together on Return on Investment (ROI) of 0.42 which means Networth and Third-Party Funds together have a relationship that is moderate and in the direction of Return on Investment (ROI). The coefficient of determination obtained is $16.81 \%$, this shows that Networth and Third-Party Funds together have a contribution to Return on Investments of $16.81 \%$, while the rest is influenced by other factors, and based on the results obtained in Hypothesis testing is that tcount $=\mathbf{0 . 3 0 2}$ while from Ttabel with a $5 \%$ error rate of 9.55. Or $0.302<9.55$ so that $\mathrm{HO}$ is accepted and $\mathrm{Ha}$ is rejected.

Keywords: Networth, Third Party Funds, ROI

\section{PENDAHULUAN}

Menurut Bambang Riyanto (2008:240), menyatakan bahwa: "Modal sendiri adalah modal yang berasal dari pemilik perusahaan dan yang tertanam di dalam untuk waktu yang tidak tertentu lamanya".

Menurut Jumingan (2014:27) menyatakan bahwa:"Modal sendiri adalah dana yang bersumber dari pihak perusahaan”.Menurut

Sutrisno
(2013:8), menyatakan bahwa:"Modal sendiri atau sering disebut equity adalah modal yang berasal dari setoran pemilik ( modal saham, agio saham) dan hasil operasi perusahaan itu sendiri (laba dan cadangan-cadangan) Dari beberapa pengertian tersebut, maka dapat dirangkum bahwa modal sendiri merupakan sejumlah uang tunai atau modal yang bersumber dari pihak perusahaan dan yang tertanam di dalam perusahaan dalam waktu yang tidak tertentu lamanya.Indikator Modal Sendiri yaitu Modal dari pihak perusahaan dan Modal yang tertanam Adapun fungsi modal sendiri menurut Malayu S.P. Hasibuan (2015 :64) antara lain untuk :1.Membiayai kegiatan operasional perusahaan 2.Investasi primer dan investasi sekunder3.Memberikan proteksi atau perlindungan kepentingan deposan 4.Memenuhi CAR terhadap ketentuan perusahaan 5.Menanggung risiko kredit atau kerugian perusahaan, 6.Mempertinggi tingkat kepercayaan SSU kepada perusahaan 7.Memberikan keamanan bagi modal asing 8.Sebagai bukti kepemilikan perusahaan. Adapun rincian komponen dari masing-masing modal sendiri menurut Malayu S.P. 
Fitria Damayanti, Ika Widyastuti

Hasibuan (2015: 62) adalah sebagai berikut: Modal Inti, Modal Disetor, Modal Pelengkap

Dana pihak ketiga merupakan sumberdana yang berasal dari masyarakat sebagai nasabah dalam bentuk simpanan giro, tabungan, deposito, dan dalam bentuk lainya.

Menurut Ismail (2010:43) menyatakan bahwa: "Dana pihak ketiga biasanya lebih dikenal dengan dan masyarakat, merupakan dana yang di himpun oleh bank yang berasal dari masyarakat luas, meliputi masyarakat individu, maupun badan usaha”

Menurut Herman Darmawi (2012:59) menyatakan bahwa: "Dana pihak ketiga adalah dana simpanan (deposit) masyarakat yang merupakan jumlah dana terbesar yang paling diandalkan oleh bank, yang terdiri darisimpanan dalam bentuk rekening giro, simpanan dlam bentuk tabungan, simpanan dlam bentuk deposito berjangka” Menurut Kasmir (2013:59) menyatakan bahwa:"Dana pihak ketiga adalah dana yang berasal dari masyarakat luas yang merupakan sumber dana terpenting bagi kegiatan operasional suatu bank dan merupakan ukuran keberhasilan bank jika mampu membiayai operasionalnya dari sumber dana ini”

Dari beberapa pengertian para ahli, maka dapat disimpulkan. Dana pihak ketiga merupakan dana yang berasal dari masyarakat baik individu maupun badan usaha, untuk disimpan uanganya di bank dengan jangka waktu tertentu dalam bentuk simpanan giro, simpanan tabungan dan simpanan deposito. Indikator dana pihak ketiga menurut Herman Darmawi, yaitu Tabungan, Deposito, Giro

Menurut Ismail (2010:43), menyatakan bahwa; 1.Simpanan Giro ( Demand Deposito) adalah simpanan yang diperoleh dari masyarakat atau pihak ketiga yang sifat penarikannya adalah dapat di tarik setiap saatdengan menggunakan cek dan bilyaet giro, sarana perintah bayar lainya atau dengan cara pemindah bukuan.2.Simpanan Deposito ( Time Deposits)Simpanan deposito merupakan jenis simpanan yang penarikanya hanya dapat dilakukan sesuai dengan jangaka waktu yang telah di perjanjikan antara bank dengan nasabah.3.Tabungan

(Saving) Tabungan merupakan jenis simpanan yang dilakukan oleh pihak ketiga yang 
Fitria Damayanti, Ika Widyastuti

penarikanya dapat dilakukan menurut syarat-syarat tertentu sesuai perjanjian antara pihak bank dengan nasabah.Menurut Lukman Syamsudin (2013:63), menyatakan bahwa :"Return On Invesment (ROI) merupakan pengukuran kemampuan perusaShaan secara keseluruhan di dalam menghasilkan keuntungan dengan jumlah keseluruhan aktiva yang telah tersedia perusahaan ".Menurut Munawir (2014:89), menyatakan bahwa :"Return On Invesment (ROI )adalah salah satu bentuk dari rasio profitabilitas yang dimaksudkan untuk dapat mengukur kemampuan perusahaan dengan keseluruhan dana yang ditanamkan dalam aktiva yang di gunakan untuk kegiatan operasinya perusahaan untuk menghasilkan keuntungan".

Menurut Sutrisno (2012:223), menyatakan bahwa: "Return on Invesment (ROI) adalaha kemampuan perusahaan untuk menghasilkan keuntungan yang akan digunakan untuk menutup investasi yang di keluarkan. Laba yang gunakan untuk menutuprasio ini adalah laba bersih setelah pajak EAT”.
Berdasarkan pengertianpengertian para ahli di atas maka dapat di simpulkan bahwa Return on Invesment (ROI) adalah kemampuan perusahaan dalam menghasilkan keuntungan. IndikatorReturn On Invesment (ROI), ROI di gunakan untuk mengukur kemampuan modalyang di investasikan dalam aktiva untuk di gunakan dalam membiayai operasional perusahaan untuk menghasilkan keuntungan bersih. ROI adalah alat ukur yang sangat umum di gunakan untuk mengukur kinerja sebuah pusat investasi.

Rumus Return on Invesment (ROI):

Laba $=\underline{\text { Erning After Tax (EAT) }} \times 100 \%$ Total Aset

Penjelasan Indikator:

1. Laba Sesudah Pajak (EAT)

Merupakan keuntungan yang di dapat oleh perusahaan setelah di kurangi pajak.

\section{Total Asset}

Jumlah keseluruhan asset atau harta yang di miliki perusahaan.

Faktor-Faktor yang mempengaruhi Return on Invesment (ROI) 
Fitria Damayanti, Ika Widyastuti

Return On Invesment (ROI) pada dasarnya di pengaruhi oleh beberapa faktor, namun secara singkat net income di bagi total investasi, Return On Invesment (ROI) adalah profit margin di kalikan perputaran aktiva.Menurut Munawir (2014:89), besarnya Return On Invesmen (ROI) di pengaruhi oleh dua faktor:1. Turnover dari operating assets (tingkat perputaran aktiva yang di gunakan untuk opersi), yang telah diuraikan dalam poin 2.Profit Margin, yaitu besarnya keuntungan operasi yang dinyatakan presentase dan jumlah penjualan bersih. Profit margin ini mengukur tingkat keuntungan yang dapat di capai oleh perusahaaan di hubungkan dengan penjulannya.

Bersanya Return on Invesment (ROI) akan berubah jika ada perusahaan profit margin atau assets turnover, baik masing-masing atu kedua-duanya. Dengan demikian maka pimpinan perusahaaan dapat menggunakan salah satu atau keduaduanya dlam rangka untuk memperbesar ROI. Usaha mempertinggi ROI dengan memperbesar profit margin adalah bersangkutan dengan usaha untuk mempertinggi efisiensi disektor prduksi, penjualan dan administrasi. Usaha mempertinggi ROI dengan memperbesar assets turnover adalah kebijakan investasi dana dalam berbagai aktiva, baik aktiva lancer maupun aktiva tetap. Hipotesis Penelitian

Hipotesis yang diajukan dalam penelitian ini merupakan pernyataan singkat dari kerangka pemikiran dan merupakan jawaban sementara atas permasalahan yang dibahas. Suatu hipotesis akan diterima jika hasil analisis data empiris membuktikan bahwa hipotesis tersebut adalah benar. Dari permasalahan yang diangkat di atas, maka hipotesis dalam penelitian ini adalah:

H1= Diduga terdapat pengaruh modal sendiri terhadap ROI

$\mathrm{H} 2=$ Diduga terdapat pengaruh dana pihak ketiga terhadap ROI

H3= Diduga terdapat pengaruh modal sendiri dan dana pihak ketiga secara bersama-sama terhadap ROI 
Fitria Damayanti, Ika Widyastuti

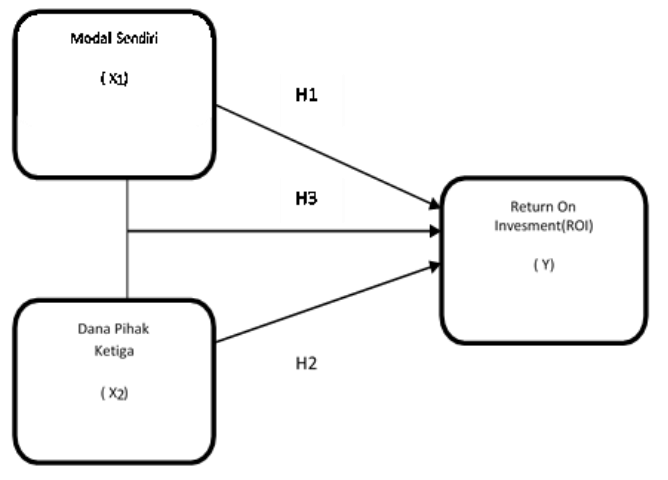

Gambar Desain Hipotesis

Secara statistik hipotesis penelitian tersebut dapat dinyatakan dengan ketentuan sebagai berikut:

H1 o; $r=0$ Diduga tidak terdapat pengaruh modal sendiri terhadap return on invesment (ROI)

$\mathrm{H} 1 \quad \mathrm{a} ; \mathrm{r} \neq 0$ Diduga terdapat pengaruh modal sendiri terhadap return oninvesment (ROI)

$\mathrm{H} 2 \mathrm{o} ; \mathrm{r}=0$ Diduga tidak terdapat pengaruh dana pihak ketiga terhadap return on invesment (ROI)

$\mathrm{H} 2 \mathrm{a} ; \mathrm{r} \neq 0$ Diduga terdapat pengaruh dana pihak ketiga terhadap return on invesment (ROI)

H3 o; $r=0$ Diduga tidak terdapat pengaruh modal sendiri dan dana pihak ketiga secara bersama-sama terhadap return on invesment (ROI)

$\mathrm{H} 3$ a; $\mathrm{r} \neq 0$ Diduga terdapat pengaruh modal sendiri dan dana pihak ketiga secara bersama-sama terhadap return on invesment (ROI).

\section{METODE PENELITIAN}

Metode penelitian merupakan teknik atau cara untuk mencari, mengumpulkan atau mencatat data yang akan digunakan untuk keperluan menyusun karya ilmiah. Menurut Sugiyono (2013:2), bahwa Metode penelitian merupakan cara ilmiah untuk mendapatkan data dengan tujuan dan kegunaan tertentu. Menurut Sugiyono (2013: 11) bahwa penelitian tingkat eksplanasi adalah penelitian yang bermaksud menjelaskan kedudukan variabel-variabel yang diteliti serta hubungan antara satu variabel dengan variabel lainnya. Berdasarkan hal ini, penelitian dapat dikelompokkan menjadi 3, yaitu: Penelitian Deskriptif, Penelitian Komparatif, Penelitian Asosiatif/hubungan. Untuk melakukan suatu penelitian, terlebih dahulu harus ditentukan populasi yang akan diteliti. Menurut Sugiyono (2013:61), bahwa populasi adalah wilayah generalisasi yang terdiri atas: objek/ subjek yang mempunyai kualitas dan karakteristik tertentu yang ditetapkan oleh peneliti untuk dipelajari dan kemudian ditarik kesimpulannya. Populasi yang digunakan dari periode sejak 
Fitria Damayanti, Ika Widyastuti

perusahaan berdiri sampai dengan tahun 2017.Menurut Sugiyono (2013:81), bahwa sampel adalah bagian dari jumlah dan karakteristik yang dimiliki populasi tersebut. Dalam penelitian ini populasinya adalah laporan laba rugi dan neraca keuangan perusahaan yang dibuat sejak PD. BPR PK Balongan berdiri pada tanggal 24 maret 1987 samapai dengan sekarang..Sampel yang diambil dalam penelitian ini adalah laporan laba rugi dan neraca keuangan perusahaan yang dibuat selama enam periode terakhir ( 2011 - 2016). Menurut Sugiyono (2014:2), menyatakan bahwa :"Variabel penelitian pada dasarnya adalah segala sesuatu yang berbentuk apa saja yang ditetapkan oleh peneliti untuk dipelajari sehingga diperoleh informasi tentang hal tersebut, kemudian ditarik kesimpulannya."Variabel-variabel yang terdapat dalam penelitian ini dapat didefinisikan sebagai berikut :Variabel Independen (Variabel Bebas)Variabel bebas dalam penelitian ini adalah modal sendiri dan Dana pihak ketiga dan Variabel Dependen (Variabel Terikat), Variabel terikat dalam penelitian ini adalah Return On Invesmen(ROI) (Y).Menurut Sugiyono
(2012: 1) menyatakan bahwa:"Metode penelitian pada dasarnya merupakan cara ilmiah untuk mendapatkan data dengan tujuan dan kegunaan tertentu" Dalam penelitian ini, penulis menggunakan metode penelitian deskriptif dan metode asosiatif. Berikut ini adalah penjelasan metode yang peneliti gunakan sebagai berikut, Menurut Sugiyono ( 2014 : 29 ) menyatakan bahwa :"Metodedeskriptif adalah statistik yang berfungsi untuk mendiskripsikan atau memberi gambaran terhadap obyek yang diteliti melalui data sampel atau populasi sebagaimana adanya, tanpa melakukan analisis dan membuat kesimpulan yang berlaku untuk umum."'Metode Asosiatif Tujuan dari penelitian ini yaitu untuk mengetahui hubungan Modal Sendiri dan Dana Pihak Ketiga Terhadap Return On Invesment. Menurut Sugiyono (2014: 89) menyatakan bahwa: "Hipotesis asosiatif merupakan suatu pernyataan yang menunjukan dugaan tentang hubungan antara dua variabel atau lebih." Metode pengumpulan data yang berhubungan dengan penelitian ini dilakukan dengan: 1.Library Research (Penelitian Kepustakaan).Penelitian dengan cara ini data dapat diperoleh 
Fitria Damayanti, Ika Widyastuti

dengan jalan melakukan penelitian laporan yang berhubungan dengan topic secara teoritis, yaitu dengan membaca dan mempelajari literatur serta pendapat para ahli yang bersumber dari bukubuku teks yang berhubungan dengan penelitian ini.2.Field Research permasalahan yang sedang diteliti, serta buku literature yang berhubungan dengan penelitian ini Uji t (Deskriptif), Menurut Sugiyono (2014: 95) (Penelitian Lapangan), Penelitian ini melakukan kunjungan langsung pada objek dimana peneliti melakukan penelitian. Metode ini dilaksanakan dengan cara melakukan: a. Wawancara b. Observasi. Jenis Data Penelitian 1. Data kuantitatif, yaitu data numeric untuk dapat menghasilkan penafsiran yang kokoh atau dengan kata lain berupa angka yang diperoleh dari laporan keuangan yang berhubungan dengan penulisan ini, seperti neraca dan laporan laba rugi pada perusahaan. 2.Data kualitatif, yaitu data yang diperoleh dalam bentuk tulisan berupa gambaran umum perusahaan, sejarah simgkat perusahaan, maupun informasi lisan yang menyangkut kebijakankebijakan yang dikeluarkan oleh pihak perusahaan. Sumber data yang digunakan dalam penelitian ini adalah data sekunder. Data Sekunder yaitu data yang telah dikumpulkan atau diolah menjadi informasi. Data sekunder yang digunakan diperoleh dari laporanmenyatakan bahwa: Statistik parametis yang dapat digunakan untuk menguji hipotesis deskriptif bila datanya interval atau rasio adalah t-test 1 sampel. Rumus yang digunakan untuk menguji hipotesis deskriptif (satu sampel) yang datanya interval atau rasio. Analisis Korelasi Tunggal Menurut Sugiyono (2014: 228) menyatakan bahwa: Teknikkorelasi ini digunakan untuk mencari hubungan dan membuktikan hipotesis hubungan dua variabel bila data kedua variable berbentuk interval atau rasio. Dalam menganalisa data ini digunakan rumus koefisien korelasi product moment sebagai berikut:

$\mathrm{r}=\boldsymbol{n} \sum \boldsymbol{x} \boldsymbol{y}-\boldsymbol{n} \sum \boldsymbol{x} \sum \boldsymbol{y}$

$\sqrt{ }\left(\boldsymbol{n} \sum \boldsymbol{X} 2-\left(\sum X\right)^{2}\right)\left(\boldsymbol{n} \sum \boldsymbol{Y}^{2}-(\boldsymbol{Y})^{\mathbf{2}}\right)$

Dimana:

$\mathrm{r} \quad=$ Korelasi product moment

$\mathrm{n} \quad=$ Jumlah data

$\mathrm{x}=$ Variabel $\mathrm{x}$

$\mathrm{y}=$ Variabel $\mathrm{y}$

analisis Korelasi Berganda Menurut Sugiyono (2012:233), menyatakan bahwa: "korelasi ganda (multiple 
Fitria Damayanti, Ika Widyastuti

correlation) merupakan angka yang menunjukan arah dan kuatnya hubungan antara dua variabel independen secara bersama-sama atau lebih dengan satu variabel dependen."

Analisis Koefisien Determinasi Menurut Sugiyono (2014: 231) menyatakan bahwa: "Koefisien determinasi disebut koefisien penentu, karena varian yang terjadi pada variabel dependen dapat dijelaskan melalui varians yang terjadi pada variabel independen." Koefisien determinasi (koefisien penentu) dinyatakan dengan rumus:

$\mathrm{Kd}=\mathrm{r} 2 \times 100 \%$

Dimana:

$\mathrm{Kd}=$ Koefisien determinasi

$\mathrm{r} \quad=$ koefisien korelasi

Uji Hipotesis (Uji-t) Asosiatif

Menurut Sugiyono (2014: 230) rumus uji t sebagai berikut:

$$
\mathrm{t}=\begin{aligned}
& \boldsymbol{r} \boldsymbol{n}-\mathbf{2} \\
& \sqrt{ } \mathbf{1}-\boldsymbol{r}^{2}
\end{aligned}
$$

Dimana:

$\mathrm{t}=$ Distribusi $\mathrm{t}$ hutang $\mathrm{r}=$ Koefisien Korelasi $\mathrm{n}=$ Jumlah data

Dengan ketentuan jika $\mathrm{t}$ hitung lebih kecil dari $\mathrm{t}$ tabel (thitung $<$ tabel) maka Ho diterima dan $\mathrm{Ha}$ ditolak $\mathrm{t}$ hitung lebih besar dari t tabel (thitung > tabel) maka Ho ditolak dan $\mathrm{Ha}$ diterima.

Uji Hipotesis (Uji-F)

Menurut Sugiyono (2014: 235) menyatakan bahwa: Uji F dilakukan untuk mengetahui signifikan atau tidaknya pengaruh variabel bebas secara bersama-sama atau simultan terhadap variabel terikatnya. Apabila hasil uji $\mathrm{F}$ hitung lebih dari $\mathrm{F}$ table berarti variabel bebas signifikan untuk menjelaskan variabel terikat Rumus uji $\mathrm{F}$

\section{HASIL DAN PEMBAHASAN}

Tabel Perkembangan Modal Sendiri

\begin{tabular}{c|ccc|}
\multicolumn{4}{|c}{ PD. BPR PK Balongan } \\
Taturn & Moda1 & Naik Turun (Rp) Perubahan (\%) \\
& $\$ 2 n d i r i$ & & - \\
2012 & $2,200,511$ & - & - \\
2013 & $2,925,753$ & 725,242 & 32,957 \\
2014 & $6,842,202$ & $3,916,449$ & 133,861 \\
2015 & $7,758,010$ & 915,808 & 13,384 \\
\hline 2016 & $8,458,801$ & 700,791 & 9,033 \\
\hline 2017 & $4,982,821$ & $(3,475,980)$ & $(41,093)$ \\
\hline
\end{tabular}

Sumber :Data primer yang telah diolah(Dalam jutaan )

Tabel Perkembangan Dana Pihak Ketiga PD. BPR PK Balongan

\begin{tabular}{c|ccc|}
\hline Tahun & $\begin{array}{c}\text { Dana Pihak } \\
\text { Ketiga }\end{array}$ & $\begin{array}{c}\text { Naik Turun } \\
\text { (Rp) }\end{array}$ & $\begin{array}{c}\text { Perubahan } \\
(\%)\end{array}$ \\
2012 & $10,078,603$ & - & - \\
2013 & $11,909,592$ & $1,830,989$ & 18,16 \\
2014 & $13,907,349$ & $1,997,757$ & 16,77 \\
\hline 2015 & $14,730,344$ & 822,995 & 5,91 \\
2016 & $19,215,292$ & $4,484,948$ & 30,44 \\
2017 & $25,021,412$ & $5,806,120$ & 30,21
\end{tabular}

Sumber: Data primer yang telah diolah (Dalam jutaan) 
Fitria Damayanti, Ika Widyastuti

Tabel Perkembangan Return on Investment (ROI)

\begin{tabular}{|c|c|c|c|}
\hline Tatun & $\begin{array}{l}\text { Return On } \\
\text { hevestment }\end{array}$ & Naik/Turun & Perubathan \\
\hline 2012 & 298 & - & - \\
\hline 2013 & 2,45 & -53 & -17.78 \\
\hline 2014 & 2,76 & 31 & -8734 \\
\hline 2015 & 2,90 & 14 & 5,07 \\
\hline 2016 & 3,16 & 26 & 0,08 \\
\hline 2017 & 3,16 & 0 & 0 \\
\hline
\end{tabular}

Sumber: Data primer yang telah diolah

Uji t Modal sendiri sebesar 0,003.

Digunakan uji dua pihak, dengan taraf signifikasi $5 \%$ dan derajat kebebasan (dk) 6-2 = 4 didapatkan nilai ttabel sebesar 2,776. Karena thitung < dari ttabel $(0,003<2,776) . \quad$ Maka Ho diterima dan Ha ditolak. Uji t Deskriptif Dana Pihak Ketiga dengan thitung sebesar 0,111. Digunakan uji dua pihak, dengan taraf signifikasi $5 \%$ dan derajat kebebasan (dk) 6-2 = 4 didapatkan nilai ttabel sebesar 2,776. Karena thitung < dari ttabel $(0,111<2,776)$. Maka Ho diterimadan Ha ditolak. Uji t Deskriptif Return on Invesment (ROI) dengan thitung sebesar 0,107. Digunakan uji dua pihak, dengan taraf signifikasi 5\% dan derajat kebebasan (dk) 6-2 = 4 didapatkan nilai ttabel sebesar 2,776. Karena thitung < dari tabel $(0,107<$ 2,776). Maka Ho diterimadan $\mathrm{Ha}$ ditolak. Analisis Korelasi Tunggal, Analisis Korelasi Modal Sendiri
Terhadap Return on Invesment (ROI) adalah Untuk mengetahui bagaimana pengaruh modal sendiri terhadap return on invesment, dimana teknik analisis data yang digunakan adalah analisis korelasi tunggal. Analisis bagaimana pengaruh modal sendiri terhadap return on investment adalah sebagai berikut

Tabel Analisis Korealasi X1 (Modal Sendiri) Terhadap Y (ROI) Pada PD.BPR PK Balongan Indramayu (Dalam Jutaan)

\begin{tabular}{|c|c|c|c|c|c|}
\hline No & $\mathrm{X} 1$ & $\mathrm{Y}$ & $\mathrm{XY}$ & $\mathrm{X}^{2}$ & $\mathrm{Y}^{2}$ \\
\hline 1 & 2.20 & 2.98 & 6.55 & 4.84 & 8.88 \\
\hline 2 & 2.92 & 2.45 & 7.15 & 8.52 & 6.00 \\
\hline 3 & 6.84 & 2.76 & 18.87 & 46.78 & 7.61 \\
\hline 4 & 7.75 & 2.90 & 22.47 & 60.06 & 8.41 \\
\hline 5 & 8.45 & 3.16 & 26.70 & 71.40 & 9.98 \\
\hline 6 & 4.98 & 3.16 & 15.73 & 24.80 & 9.98 \\
\hline$\sum$ & 33.14 & 17.41 & 97.47 & 216.40 & 50.86 \\
\hline
\end{tabular}

Sumber: Data primer yang telah diolah

diperoleh hasil koefisien korelasi antara modal semdiri terhadap Return on Invesment (ROI) sebesar 0.38 (mempunyai hubungan rendah dan mempunyai arah positif).

Tabel Analisis Korealasi X2 (Dana Pihak Ketiga) Terhadap Y (ROI) PadaPD.BPR PK Balongan Indramayu (dalam jutaan)

\begin{tabular}{|c|c|c|c|c|c|}
\hline No & $\mathrm{X} 1$ & $\mathrm{Y}$ & $\mathrm{XY}$ & $\mathrm{X}^{2}$ & $\mathrm{Y}^{2}$ \\
\hline 1 & 10,07 & 2.98 & 30,00 & 101,40 & 8.88 \\
\hline 2 & 11,90 & 2.45 & 29,15 & 141,61 & 6.00 \\
\hline 3 & 13,90 & 2.76 & 38,36 & 193,21 & 7.61 \\
\hline 4 & 14,73 & 2.90 & 42,71 & 216,97 & 8.41 \\
\hline 5 & 19,21 & 3.16 & 60,70 & 369,02 & 9.98 \\
\hline 6 & 25,02 & 3.16 & 79,06 & 626,00 & 9.98 \\
\hline$\sum$ & 94.83 & 17.41 & 279.98 & 1648.21 & 50.86 \\
\hline \multicolumn{5}{|c|}{ Sumber: Data primer yang telah diolah }
\end{tabular}


Fitria Damayanti, Ika Widyastuti

Diperoleh hasil koefisien korelasi antara dana pihak ketiga terhadap Return On Invesment (ROI) sebesar 0.67 (mempunyai hubungan kuat dan mempunyai arah positif).

Tabel Analisis Korealasi X1 dan X2 Pada PD.BPR PPK Balongan

\begin{tabular}{|l|c|l|c|l|l|}
\hline & $\mathrm{X} 1$ & $\mathrm{X} 2$ & $\mathrm{X} 1^{2}$ & $\mathrm{X} 2^{2}$ & $\mathrm{X} 1 \mathrm{X} 2$ \\
\hline 1 & 2.20 & 10,07 & 4.84 & 101,40 & 22.15 \\
\hline 2 & 2.92 & 11,90 & 8.52 & 141,61 & 34.74 \\
\hline 3 & 6.84 & 13,90 & 46.78 & 193,21 & 95.07 \\
\hline 4 & 7.75 & 14,73 & 60.06 & 216,97 & 114,15 \\
\hline 5 & 8.45 & 19,21 & 71.40 & 369,02 & 162,32 \\
\hline 6 & 4.98 & 25,02 & 24.80 & 626,00 & 124,59 \\
\hline$\sum$ & 33.14 & 94.83 & 216.40 & 1648.21 & 553,02 \\
\hline \multicolumn{7}{|c|}{ Sumber : Data primer yang telah diolah }
\end{tabular}

Di dapat koefisien korelasi sebesar 0.42 dengan taksiran koefisien korelasi positif jadi dapat disimpulkan bahwa pengaruh modal sendiri dan dana pihak ketiga terhadap return on invesment (ROI) bernilai sedang dan mempunyai arah positif.

Analisis koefisien determinasi digunakan untuk mengukur pengaruh besarnya variabel independen terhadap variabel dependen. Analisis Koefisien Determinasi Besarnya Modal Sendiri Terhadap Return On Invesment (ROI) Untuk mengukur berapa besar kontribusi pengaruh besarnya modal sendiri terhadap return on invesment, maka digunakan perhitungan koefisien determinasi yaitu sebagai berikut:

(1) $\mathrm{Kd}=\mathrm{r}^{2} \times 100 \% \mathrm{Kd}$ $\mathrm{Kd}=14.44 \%$

Dari hasil perhitungan diatas diperoleh koefisien determinasi sebesar $14.44 \%$. Kontribusi yang diberikan modal sendiri terhadap return on invesment yaitu sebesar $14.44 \%$ dan sisanya $85,56 \%$ dipengaruhi oleh variabel lain yang diteliti.

Analisis Koefisien Determinasi Besarnya Dana Pihak Ketiga Terhadap Return On Invesment (ROI)

Untuk mengukur berapa besar kontribusi pengaruh besarnya dana pihak ketiga terhadap return on invesment, maka digunakan perhitungan koefisien determinasi yaitu sebagai berikut:

$$
\begin{aligned}
& \mathrm{Kd}=\mathrm{r}^{2 \times} 100 \% \\
& \mathrm{Kd}=44.89 \%
\end{aligned}
$$

Dari hasil perhitungan diatas diperoleh koefisien determinasi sebesar $44.89 \%$. Kontribusi yang diberikan dana pihak ketiga terhadap return on invesment yaitu sebesar $44.89 \%$ dan sisanya $55,11 \%$ dipengaruhi oleh variabel lain yang diteliti. 
Analisis Koefisien Determinasi Besarnya Modal Sendiri dan Dana Pihak Ketiga Secara Bersama - sama (simultan) Terhadap Return On

$$
\text { (2) } \begin{aligned}
\mathrm{Kd} & =\mathrm{r}^{2} \times 100 \% \\
\mathrm{Kd} & =16,81 \%
\end{aligned}
$$

Dari hasil perhitungan diatas diperoleh koefisien determinasi sebesar $16,81 \%$. Kontribusi yang diberikan modal sendiri dan dana pihak ketiga secara bersama-sama (simultan) terhadap return on investment yaitu sebesar $16,81 \%$ dan sisanya $83,81 \%$ dipengaruhi oleh variabel lain yang diteliti.

Uji t Pengaruh Modal Sendiri Terhadap Return on Invesment

Untuk mengetahui ada tidaknya pengaruh Modal Sendiri terhadap Return On Invesment, maka digunakan uji t. berdasarkan data yang diperoleh maka besarnya thitung adalah sebagai berikut: diperoleh penerimaan Ha untuk nilai-nilai thitung <ttabe $(0,822<$ 2,776). Dengan kata lain Ho ditolak dan Ha diterima, berarti Modal Sendiri terhadap Return on Invesment pada PD BPR PK Balongan tidak memiliki pengaruh.

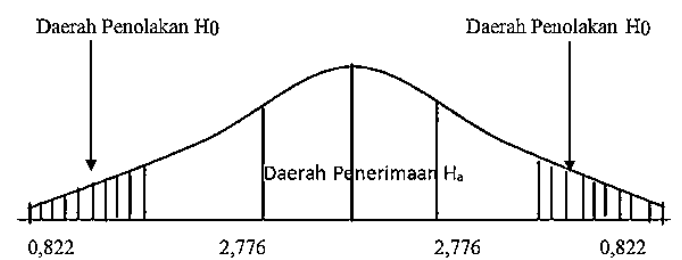

Gambar Uji Hipotesis Dua Pihak X1 terhadap Y

Pengaruh Dana Pihak Ketiga Terhadap Return on Invesment (ROI)

Untuk mengetahui ada tidaknya pengaruh dana pihak ketiga terhadap return on investment, maka digunakan uji t. Berdasarkan data yang diperoleh maka besarnya thitung adalah sebagai berikut: diperoleh penerimaan Ha untuk nilai-nilai thitung < tabel $(1,805<$ 2,776). Dengan kata lain Ho ditolak dan Ha diterima, berarti pengaruh dana pihak ketiga terhadap return on investment tidak memiliki pengaruh.

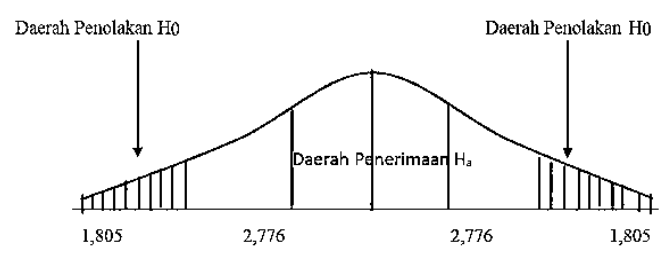

Gambar Uji Hipotesis Dua Pihak X2 terhadap Y

Uji F, Uji Hipotesis Pengaruh Modal Sendiri (X1) dan Dana Pihak Ketiga (X2) terhadap Return On 
Fitria Damayanti, Ika Widyastuti

Invesment $(\mathrm{ROI})(\mathrm{Y})$ Dalam pengujian ini dilakukan dengan tingkat kepercayaan $5 \%$ atau 0,05 dalam hal ini untuk mengetahui Ftabel dapat diuji dengan rumus $\mathrm{dF} 1=3-1=2$, sedangkan $\mathrm{dF}_{2}=6-3=3$, maka didapat nilai Ftabel adalah 9,55. Berdasarkan hasil diatas maka dapat disimpulkan bahwa Fhitung0,302< Ftabel 9,55. Dengan demikian dapat disimpulkan Ho ditolak dan Ha diterima, artinya tidak terdapat pengaruh antara modal sendiri dan dana pihak ketiga secara bersama-sama terhadap return on invesment.

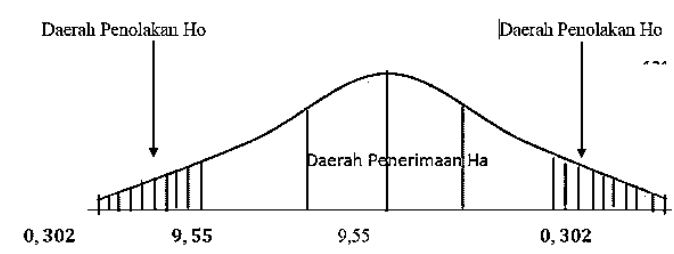

KESIMPULAN DAN SARAN

Kesimpulan

3. Kondisi modal sendiri pada PD BPR PK Balongan Indramayu selama enam tahun mengalami perubahan setiap tahunnya. Perkembangan modal sendiri selama enam tahun dari tahun 2012 sampai dengan 2017 dimana terjadi kenaikan yaitu pada tahun 2014 sebesar $133,861 \%$ dan penurunan terjadi pada tahun 2017 yaitu $41,093 \%$.
4. Kondisi dana pihak ketiga PD BPR PK Balongan Indramayu selama enam tahun mengalami perubahan setiap tahunnya. Perkembangan dana pihak ketiga selama enam tahun dari tahun 2012 sampai dengan 2017 dimana terjadi kenaikan pada tahun 2016 yaitu $30,44 \%$ dan penurunan terjadi pada tahun 2015 yaitu 5,91\%.

5. Kondisi return on invesment pada D BPR PK Balongan Indramayu selama enam tahun mengalami perubahan setiap tahunnya. Perkembangan return on invesment selama enam tahun dari tahun 2012 sampai dengan 2017 diketahui ratarata return on invesment adalah $\mathrm{Rp}$ 2.90. Dengan return on invesment yang terbesar pada tahun 2015 dan 2016 senilai Rp3,16. Dan return on invesment terendah pada tahun 2012 senilai Rp2,45.

6. Berdasarkan hasil analisis dan pengujian data modal sendiri (X1) terhadap return on invesment $(\mathrm{Y})$ diperoleh korelasi $\mathrm{r}=0,38$ yang artinya bahwa variabel modal sendiri mempunyai pengaruh rendah dan berbanding terbalik terhadap return on invesment pada 
Fitria Damayanti, Ika Widyastuti

PD BPR PK Balongan . Hasil

koefisien determinasi $\mathrm{KD}=42,51$

$\%$ artinya bahwa variabel modal sendiri memberikan kontribusi terhadap return on invesment sebesar 42,51 \% , sedangkan sisanya $57,49 \%$ dipengaruhi oleh faktor lain yang tidak diteliti oleh peneliti. Adapun hasil dari uji hipotesis, maka nilai thitung sebesar 0,822 sedangkan tabel 0,822, ini berarti bahwa thitung $<$ tabel $(0,822<2,776)$ maka dapat disimpukan bahwa $\mathrm{H} 10$ ditolak, artinya tidak terdapat pengaruh antara perputaran modal sendiri terhadap return on invesment .

7. Berdasarkan hasil analisis dan pengujian data dana pihak ketiga(X2) terhadap return on invesment (Y) diperoleh hasil analisis korelasi $\mathrm{r}=0,67$ yang artinya bahwa variabel dana pihak ketiga mempunyai pengaruh yang kuat dan berbanding terbalik terhadapreturn on invesment pada PD BPR PK Balongan . Hasil koefisien determinasi $\mathrm{KD}=1,805$ $\%$ artinya bahwa variabel dana pihak ketiga memberikan kontribusi terhadap return on invesment sebesar $1,805 \%$, sedangkan sisanya $39,78 \%$ dipengaruhi oleh faktor lain yang tidak diteliti oleh peneliti. Adapun hasil dari uji hipotesis, maka nilai thitung sebesar1,805 sedangkan ttabel 2,776, ini berarti bahwa thitung <ttabel $(1,805<2,776)$ maka dapat disimpukan bahwa $\mathrm{H}_{2} \mathrm{O}$ ditolak, artinya tidak terdapat pengaruh antara dana pihak ketiga terhadap return on invesment.

8. Berdasarkan hasil analisis dan pengujian data modal sendiri(X1) dan dana pihak ketiga (X2) terhadap return on invesment (Y) diperoleh hasil analisis korelasi $\mathrm{r}=$ 0,42 yang artinya bahwa variable modal sendiridan dana pihak ketiga mempunyai pengaruh sedang dan searah terhadap return on invesment pada PD BPR PK Balongan . Hasil koefisien determinasi $\mathrm{KD}=16,81 \%$ artinya bahwa variabel modal sendiridan dana pihak ketiga secara simultan memberikan kontribusi terhadap return on invesment sebesar 16,81 $\%$, sedangkan sisanya $25,35 \%$ dipengaruhi oleh faktor lain yang tidak diteliti oleh peneliti. Adapun 
Fitria Damayanti, Ika Widyastuti

hasil dari uji hipotesis, maka nilai thitung sebesar 0,302 sedangkan Ftabel 9,55, ini berarti bahwa thitung $<$ Ftabel $(0,302<9,55)$, maka nilai tersebut dinyatakan masih memiliki pengaruh, tetapi tidak signifikan, dan hipotesis ditolak. Dengan Demikian dapat disimpulkan bahwa tidak adanya pengaruh modal sendiri dan dana pihak ketiga secara simultan terhadap return on invesment.

\section{Saran}

1. PD BPR PK Balongan diharapkan dengan peningkatan modal sendiri dapat meungkinkan perolehan laba yang lebih besar. Dengan modal sendiri yang semakin meningkat akan memberikan pembagian deviden yang besar pula bagi pemilik.

2. PD BPR PK Balongan diharapkan dapatmeningkatkan pengumpulan dana dari masyarakat dengan membuat produk simpanan dan deposito yang lebih menarik seperti dengan adanya undian berhadiah, atau bunga yang kompetitif, sehingga masyarakat lebih tertarik untuk menyimpan uangnya tersebut.

3. PD BPR PK Balongan diharapkan dapat memanfaatkan modalnya untuk meningkatkan laba melalui pemberian kredit yang lebiih hatihati kepada nasabah, agar modal yang diinvestasikan dalam kredit mampu memberikan tingkat penegembalian yang diharapkan, dengan laba yang maksimal dan penggunaan modal yang efesien akan memberikan return on invesment yang besar, sehingga kegiatan usaha perusahaan akan lebih berkembang.

4. Modal Sendiri pada PD BPR PK Balongan merupakan modal dari pemerintah dari pemerintah Kabupaten Indramayu harus dikelola dengan efektif dan efesien untuk memperoleh laba yang maksimal, sehingga laba yang besar akan memberikan deviden yang besar pula pemerintah daerah Kabupaten Indramayu untuk meningkatkan Pendapatan Asli Daerah (PAD).

5. Pengumpuan dan penghimpunan 
Fitria Damayanti, Ika Widyastuti

dana pihak ketiga yang berasal dari masyarakat harus dimanfaatkan dengan baikdengan menggulirkan kembali melalui pemberian kredit kepada masyarakat agar dana tersebut dapat memberikan selisih lebih terhadap beban bunga simpanan dengan bungan kredit yang diberikan menjadi sumber pendapatan dari PD BPR PK Balongan.

6. Modal Sendiri dan Dana Pihak Ketiga sebagai sumber modal PD BPR PK Balongan yang jumlahnya besar diharapkan dapat memberikan return on invesment yang tinggi, dengan melakukan perluasan usaha berupa membuka peluang baru atau diverifikasi produk untuk memperoleh pendpatan non operasional lain yang tinggi lagi.

\section{DAFTAR PUSTAKA}

Riyanto, Bambang. 2013. Dasar-dasar Pembelanjaan

Perusahaan.BPFE.

Darmawi, Herman. 2012. Manajemen
Ismail. 2010. Manajemen Perbankan.

Kencana: Jakarta. Jumingan. 2014. Analisa Laporan Keuangan, Jakarta: Bumi Aksara. Kasmir. 2013. Bank Dan Lembaga Keuangan Lainnya. PT Raja Grafindo

Syamsudin, Lukman. 2013. Manajemen Keuangan Perusahaan.Rajawali pers: Jakarta.

Hanafi, Mamduh M.dan Abdul Halim. 2012. Analisis Laporan Keuangan. UPP STIM YKPN: Yogyakarta

Munawir. 2014. Analisa Laporan Keungan.liberty: Yogyakarta. Sugiyono.2012. Statistika Untuk Penelitian.ALFABETA:

Bandung. Sugiyono. 2014. Statistika Untuk Penelitian. ALFABETA: Bandung. Sugiyono.2016. Metode Penelitian Kombinasi.

ALFABETA: Bandung.

Sutrisno.2012. Manajemen Keuangan” Teori Konsep dan Aplikasi" Ekonisa: Yogyakarta.

Ratna Ayu L, Analisis

Pengaruh Pendanaan dari Luar Perusahaan Modal Sendiri Perbankan. Bumi Akasa: Jakarta. 
Fitria Damayanti, Ika Widyastuti

Terhadap

Tingkat Profitabilitas,

http://jurnalmahasiswa.unesa.ac.id/artic

le/1202/57/article.pdf.

Maman Suherman, Pengaruh Dana

Pihak Ketiga Terhadap

rentabilitas

http://lppm.unsil/ac.id.files/2014/11/1.h

.maman-s.pdf.

Hastuti, Pengaruh kebijakan deviden BUMN terhadap Return On invesment (ROI)

http://repository.unhas.ac.id/bistream/h

anle/123456789/13009/skripsi\%2

0Hastuti

20\%28A21111313\%29.pdf?sequ

ence $=1$. 